\title{
Appointed Elites in the Political Parties - Albania Case
}

\author{
Anjeza Xhaferaj \\ The European University of Tirana \\ e-mail: axhaferaj@uet.edu.al
}

\section{Doi:10.5901/ajis.2013.v2n3p307}

\begin{abstract}
The paper aimes at exploring the relationships that exist between party structure, party system, patronage and the appointments of the political elites. It is focused on the extent to which political parties can control the allocation of jobs as well as find out which are the institutions over whom the political parties can exercise power; the extent to which historical legacies influence patronage patterns; the extent to which party patronage is exercised in a 'majoritarian' as opposed to a more 'consensual' manner across the spectrum of political parties; and the relationship that exist between the structure of the party, the appointment of political elites and patronage. The conclusion is that the party in public office and its allies in the coalition cabinet control the post of ministers and vice-ministers. While this last ones control the posts of their subordinates, it is hard to understand whether they select the employees from the party pool or from their personal networks. The other finding is that the structure of the party creates strong links between patronage and appointment, these last ones done with the scope of having control over government resources and distribution of resources. On the other hand the research didn't prove any link between historical legacies and patronage and party system and patronage.
\end{abstract}

Keywords: party patronage, appointed elites, party structure, historical legacies, electoral system

\section{Introduction}

The aim of this paper is to analyze the process of elite 'recruitment' in the political parties of Albania. It seeks to contribute to the limited literature on the political parties in Albania and on another level on the limited research on the relation that exists between party structure, political appointments and patronage in Albania. Even though it is considered common knowledge that patronage and clientelism are among the main features the Albanian political scene, there is no research on this aspect and in general on political parties.

According to Blondel 'the organisation of the political system, and in particular its presidential or parliamentary structure, the natyre of the party system with its consequential effect on the single party or coalition character of the government .... constitute 'causes' of the development of particular forms of relationships" (1995, p.31). In this same vein I argue that the party structure and the type of party system influence the appointment of elites in positions in public and semi-public life. The political parties in Albania are mass parties and consequently the strategy of party elites is to use public offices for a twofold purpose: as a reward for loyalty to active party members who in return serve as a mechanism of control over the public administration in order to ensure what Daadler commented as 'the reach of the party within the polity' (1966). The party activists are to be found at all levels of the public administration, even though this is hard to prove (Kopecký and Mair, 2011, p.3). While one can easly find the political membership of ministers and vice-ministers and to a certain extend of general secretaries and advisers, it is more difficult to find such information for the positions of directors and specialist and even more difficult for lower positions. The definition offered by Kopecký and Mair considers patronage as 'an organizational and governing resource rather than as an electoral resource or as a form of linkage between citizens and parties' (2011, p.2). However this definition is valid in matured democracies (p.2), while Albania cannot be considered as such (Freedom House, 2012). Therefore, patronage will be explored in all these three dimenssions.

The study will focus on the period $2005-2012$, period where the party in public office or the party government (Katz in Blondel, 1994, p.6) is the Democratic Party of Albania. During this period the Democratic Party of Albania has won two general elections which are conducted based on different electoral systems and produced different party coalitions and cabinets. Consequently it will help to explore if the electoral system, party system and the type of cabinet influence the appointment of political elites in the public and semi-public posts. Furthermore, in this period, the political parties could be considered as consolidated and as such they display clear patterns in the appointment of political elites.

The period 1990-2004 is not taken in this analysis for three reasons. The first one is linked with the sheer newness 
of the democratic system. The multiparty system in Albania was established in 1990. Therefore it is hard to discern a permanent feature that characterizes the process of elite appointment in the political parties. This is especially true in the first decade when one cannot distinguisht between party members advancing within the party and those coming from other spheres of social and economic life. Furthermore, party loyalties and coalition patterns were characterized by volatility with members moving from one party to the other or creating splinter parties (Biberaj, 1998, p.220, 275, 423; DR, 1991, p.4; Krasniqi, 2009). In addition, during the period 1990-1997, time when the Democratic Party of Albania was in power, it is difficult to classify the appointment of people in state posts in terms of patronage, since 'following the transition to democracy, the new parties in power devoted considerable efforts to clearing out and counter-acting the extensive patronage appointments which had been inherited from the former communist regimes. ... [T]he new democratic governments [were] obliged to sweep away the old appointees and to put others in their place in order to cement the democratic transition' (in Kopecký and Mair, 2011).

The second reason is that it is hard to collect information on the political appointments during 1997-2004, time when the Socialist Party of Albania was in power, reason being that at this distance in time it is hard to find who have worked since no archives is available for research. With the estabishment of an office of European Commission in Albania in 2002, which began the publication of Country Progress Reports, the period 2005 and onward is researchable to a certain extend. The third reason is linked with the historical heritage of the Socialist Party as a successor of the former communist party, the Labor Party of Albania. There is a vast literature on the changes that the former communist parties have undergone to survive the transformation of the system (Bozòki \& Ishiyama, 2002; Grzymala-Busse, 2002; 2006). These changes are very much linked with the structure and the organization of the party, which in turn has influenced the model of political elite appointments. While path dependency theories (Collier \& Collier, 1991; Mahoney \& Snyder, 1999; Mahoney, 2000 \& 2001; Pierson, 2000 \& 2004) might be applied on the Socialist Party of Albania, they cannot be applied as such on the Democratic Party of Albania since its inception in 1990 coincides with the critical juncture of the system (the transition from communist system to democracy) and the moment of origin and that of critical juncture cannot coincide (Collier \& Collier, 1991, 30). The following table clearly illustrate that the moment of origin and that of the critical juncture should have a distance in time from each other:

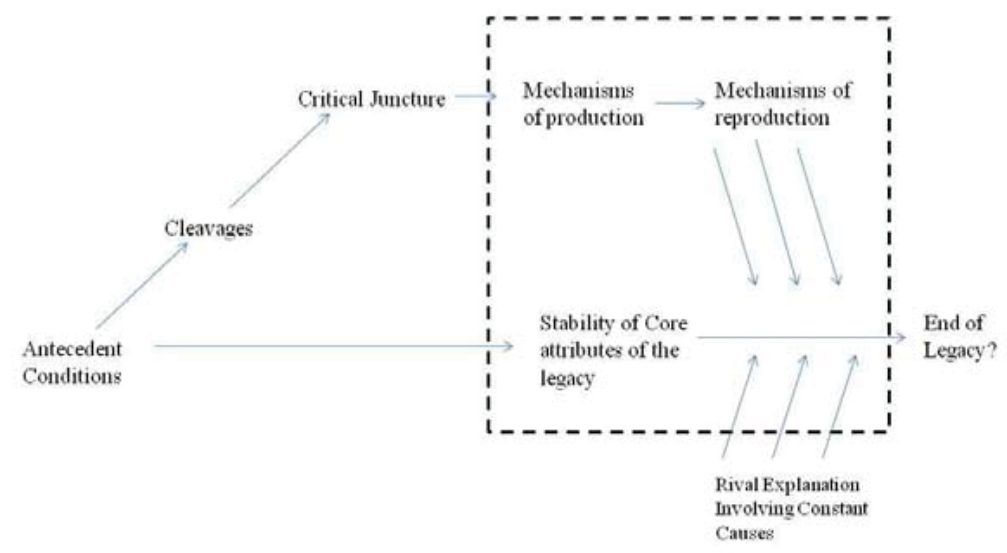

Therefore, I might anticipate that due to different historical backgrounds the Democratic Party of Albania and the Socialist Party display different patterns in the appointment of political elites. However this is not the scope of this study, which will focus on the appointment of political elites in the Democratic Party of Albania during the period 2005-2012.

The research will draw on the theoretical framework designed by Kopecký and Mair (2011) on the relation that exists between political parties and appointed elites which contend that 'parties are increasingly open, network-like organizations, with a flexible set of programmatic goals represented and implemented by individuals politicians and ministers, and operating within a dispersed and complex multi-level system of government'. The relations between party and the multi-level government positions are characterized by patronage. With party patronage is understood 'the power of parties to appoint people to positions in public and semi-public life, with the scope of the patronage then being considered to be the range of positions so distributed' (Kopecký and Mair, 2011). Furthermore, the research will draw on the theoretical framework of Blondel with regard to the institutional and behavioural factors which account for the type of the relationship and the plane on which this relationship takes place. The three planes identified by Blondel are: a) 
appointments; b) policy making and; c) patronage (1994,7-8; 1995, p.1).

The research is focused on the following points:

1. The extent to which political parties can control the allocation of jobs as well as find out which are the institutions over whom the political parties can exercise power. Subject of analysis have posts of ministers and vice-ministers, posts in high level in ministries.

2. The extent to which historical legacies influence patronage patterns.

3. The extent to which party patronage is exercised in a 'majoritarian' as opposed to a more 'consensual' manner across the spectrum of political parties. While Albania has for long been a 'Westminster' model of democracy (Lijphart 1999) - with the change of the electoral system in 2009 from mainly majoritarian towards proportional it has shifted a bit towards a more consensual model of democracy.

4. The relationship that exist between the structure of the party, the appointment of political elites and patronage.

\section{Party Control on the Allocation of Jobs in the Public Administration}

The politicization of the civil service in Albania has been widely studied and researched (Cohen, 2010; Elbasani, 2011; Bogdani and Loughlin, 2007; EU Albania Progress Reports 2002-2012; Albanian Helsinki Committee, 2011). The Parliamentary Commission for the 'Investigation on the Dissmissals in the Public Administration' reported that within three months after coming to power, the Democratic Party of Albania has dissmissed 379 persons from their posts in the Council of Ministers and line ministries and 14,074 persons in country level (2006, p.3-5), who were all replaced by people affiliated with the Democratic Party or with its coalition parties. The following table shows the number of the dissmissed persons in each ministry:

\begin{tabular}{|c|l|c|c|}
\hline No & \multicolumn{1}{|c|}{ Institution } & Director & Chief of Sector \\
\hline 1 & Council of Ministers & 18 & 5 \\
\hline 2 & Ministry of Interior & 16 & 11 \\
\hline 3 & Ministry of Economy, Trade and Energy & 6 & 23 \\
\hline 4 & Ministry of Agriculture, Food and Consumer Protection & 9 & 17 \\
\hline 5 & Ministry of Turism, Culture, Youth and Sports & 4 & 5 \\
\hline 6 & Ministry of Integration & 1 & 6 \\
\hline 7 & Ministry of Environment, Forests and Water Administration & 4 & 6 \\
\hline 8 & Ministry of Labor, Social Affairs and Equal Opportunities & 6 & 3 \\
\hline 9 & Ministry of Public Work, Transport and Telecommunication & 13 & 13 \\
\hline 10 & Ministry of Finance & 9 & 14 \\
\hline 11 & Ministry of Defence & 6 & 13 \\
\hline 12 & Ministry of Health & $?$ & 7 \\
\hline 13 & Ministry of Justice & 4 & 12 \\
\hline 14 & Ministry of Education & $?$ & 3 \\
\hline 15 & Ministry of Foreign Affairs & 6 & 14 \\
\hline
\end{tabular}

The same report indicates that in addition to the masive purge in the ministries, the political appointments reached institutions such as Customs, Administration of Taxes and Tariffs, State Police and the like. The following table shows the number of dissmissals in these institutions:

\begin{tabular}{|l|c|}
\hline \multicolumn{1}{|c|}{ Institutions } & No. of Dissmissals \\
\hline Council of Ministers and line ministries & 658 \\
\hline Subordinate Institutions to the Council of Ministers & 363 \\
\hline Administration of Taxes and Tariffs & 610 \\
\hline Customs & 546 \\
\hline Subordinate Institutions to the line ministries and public entities & 11356 \\
\hline State Police & 441 \\
\hline
\end{tabular}

Even though the legal framework was in place and EU was observing, the process of politically motivated dismissals took place. Furthermore, in the eve of the general elections of 2009, the government took the decision to employ around 1,700 temporary staff as a measure to install political militants in the initial period transition and thus to get control over the state (Elbasani, 2011, p.17; Cohen, 2010, p.19). Cohen argues that the 'members of the political elite often under-estimate the 
improtance of public administrative reform for economic development and, in most cases, incumbent decision-makers simply wanted to maintain control of bureaucracy in order to distribute positions and perks to their supporters (2010, p.16).

The European Commission has consistently reported that public administration in Albania is politicized. In the Progress Report of 2005 is written:

The Albanian civil service remains hindered by a pervasive lack of understanding of the need for, or will to implement, a real separation between the political and administrative levels. Political appointments, down to Director level in most ministries are still the norm, notably, the appointment of Secretaries General remains political, so the potential role of Secretaries General-that of translating ideas into policy, and of effective personnel management to ensure effective policy execution and service delivery-is severely compromised. Ministries have often been too involved in the day-to-day running of their ministries, and unwilling to leave such duties to permanent civil servants (p.12).

The succeeding progress reports have reported the same problem. The appointment to senior and mid-level positions were political, thus restricting the growth of a professional senior civil service (European Commission, 2006, p.7; 2007, p.8). Both 2011 and 2012 report comments that this problem is persistent. Staff turnover remains one of the weaknesses of the system $(2012,9)$ and 'establishing an independent, merit-based and professional civil service free from political interference has yet to be achieved' (2011, p.10). Even though there is a legal framework to organize the recruitment of staff in vacant positions, the parties of coalition government can influence such appointments:

As provided by the civil service law, the civil service in Albania is basically a position-based system with some elements of a career mechanism. Such a system is subject to higher risks of politically motivated staff turn-over than in a fully career-based system. The total number of public employees is about 90,000, including 15,000 in local and regional administrations. Of these, only about 5,000 are civil servants. The civil service law regulates civil servant recruitments.... The law provides for open competitions as the only means of recruiting civil servants. Most stages of open competitions are transparent. However, the final stage and the recruitment decision is left exclusively to the discretion of the line manager concerned. An exception to the rule of open competitions is temporary employment. Over the last few years there has been a relatively high share (on average more than 20\%) of vacancies filled by employees under temporary contracts. Most staff recruited on a temporary basis tend to be confirmed subsequently in open competitions. ... There has in general been a high turnover of civil servants in recent years due to politicisation of recruitment practices. (European Commission, 2010, p.15).

The temporary contracts are used by the political parties to ensure the appointments of their members in public posts in order to ensure control over the such posts. The particularly high number of such contracts (European Commission, 2012, 11), indicate that the political parties have deeply penetrated in the public administration. The share vacancies filled by temporary contracts is around $20 \%$ of all vacancies which is high $(2009$, p.9).

As one may observe there is a consistency in staff turnover during the period under research which indicates that vacant posts are created and filled based on political criteria aimed at exerting influence and control over the public administration, especially in the Council of Ministers and line ministries and thus over policy making (Blondel, 1995, p.3). However these statistics, beeing the same throughout the period, do not help to distinuish any pattern of political appointments even though there are two different cabinets and coalitions governments which are produced as a result of two diffrent electoral systems.

\section{Historical - Structural Legacies and Party Patronage - Communist Legacy}

The theory of communist legacy argues that the nature of the prior regime exercises constraining factors in the transition process of post-communist countries. The former communist countries are characterized by a diversity in the democratic development and party-system formation. The cause of such diversity lies in the different historical legacies of these countries (Kietschelt, 1999,p.19; 2001, p.299). It is a logic of cause and effect, where the past has influenced the nature of the communist regimes considered as a 'passing phase in a longer trajectory of economic, institutional, and cultural development', and the nature of communist regime influenced the democratic institutions and party system formations. The post-communist democratic quality is influenced by the historical legacies and democratic institutions (Kitschelt, 2001, p.45, p.307).

According to Kitschelt et al. there are three types of communist rule: patrimonial communism, national accommodative and bureaucratic authoritarian (1999, p.24-27). Albania falls in the category of patrimonial communism which emerged in societies that have not experienced modernization (p.24, p.42). The countries that fall in the category of patrimonial communism had no dissidence during communism. In the transition period, a dissatisfied part of the 
communist elite, managed to organize itself and form opposition parties, before anti-communists could mobilize for a liberal-democratic order. The post-anti-communist parties produced weak programmatic crystallization. Their discourse was focused on anticommunism, thus framing the inter-party political competition not in terms of right-left dimension, but on the antagonism between apologists and opponents of the former communist regime (Kitschelt et.al, 1999, p.388). Furthermore polities that have inhereted patrimonial communism tend to offer a more fertile ground for clientelistic party politics and patronage (p.52). This explanatory framework does not differentiate between communist successor parties and opposition parties, since these lasts do not exist as such. The political elites of 'opposition' parties have been part of the communist political elite and as such have inherited its features. Cohen is in the same vein when argues that the politicized character of the public administration is due to the 'regions's deeply embedded tradition of political interference in administrative decisions, and the lack of a clear division between the public and private spheres' (2010, p.16).

Even though this approach to a certain extend could offer some explanatory framework, still it does not explain how patronage patterns develop with the passing of time and in different cabinet types and coalition governments. Therefore it is essential to examine the developent of patronage in relation to the party structure and coalition.

\section{Party System - Cabinet Type - Appointment of the Political Elite}

Patronage and political appointments are strongly linked and in this sense patronage is established when government makes favours to political parties by allowing them to advance candidates as members of the government. Such link, Blondel considers as 'a trade-off between the government, which wishes to see given policies adopted, and parties, which wish to obtain favours' $(1995$, p.3). At this point it is important to see who is in the government, or better what type of cabinet is in place and who appoint whom. Does the government makes favours to the party or it is the party who exerts control over the government?

Albania is a parliamentary system and according to Shugart, parliamentary systems tend to produce strong parties $(1998$, p.3). Furthermore, Shugart argues that 'there tends to be an inverse relationship between the strength accorded to party leaders and the strength accorded to executives' (1998,p.3). Similarly, Hanley et.al. comments that 'the choice of ... a strong parliamentary regime can be regarded as much (if not more) an effect of strong political parties' (2007, p.20; 2008, p.419). The democratic party of Albania is considered a strong party (Xhaferaj, 2010). For reaching to this conclusion I am refering to the conceptualization of Hanley et al. (2007, p.6; 2008, p.408) of party success. In this case success is seen as an indicator of strength because it is has been present in the life of DP since its inception in 1991. Furthermore, the Democratic Party is developed through penetration and such development produces strong institutions (Panebianco, 1988, 63). Therefore, it is not the government, but rather the party in public office which allocate the distribution of posts of Ministers and vice-Ministers. All the ministers and vice ministers are party members in the high hierarchical levels of the party organization.

When the cabinet is a single majority one (Lijphart, 1999, p.90) it is clear that the party in public office control all the appointments in government. However the situation is different when there is a coalition government. The appointment in the vacant positions is done through negotiations which are largely depended from the share of seats that the political parties have in parliament. Blondel comments that 'the links between appointments and patronage ... often exists as parties more than occasionally join the government with an eye to the favours which can be distributed. This practice takes the form of a 'colonisation' of the ministries and of the tentacles of these ministries in the public sector' $(1995$, p.11). Furthermore Blondel contends that such patronage arrangements most likely occur in coalition government where parties are very strong and have a large membership (p.11) which is the case of Albania.

The following tables show the distribution of the posts of ministers and vice ministers for the period that Democratic Party has been in power:

Table: Electoral Cycle: 2005-2009

\begin{tabular}{|l|c|c|c|c|c|c|}
\hline \multicolumn{1}{|c|}{ Party } & DP & DCP & RP & AAP & NF & PL \\
\hline Position & 11 & 0 & 2 & 1 & 0 & 0 \\
\hline Minister & 20 & 4 & 3 & 1 & 1 & 1 \\
\hline Vice-Ministers & &
\end{tabular}


Table: Electoral Cycle: 2009-2013

\begin{tabular}{|l|c|c|c|c|c|c|c|c|c|}
\hline \multicolumn{1}{|c|}{ Party } & DP & SMI & RP & HRUP & DKP & DA & NF & PJIU & LDU \& PL \\
\cline { 1 - 10 } Position & & 3 & 1 & 1 & & & & & \\
\hline Minister & 9 & 3 & 2 & 1 & 1 & 1 & 1 & 2 & 2 \\
\hline Vice-Ministers & 18 & 6 & 2 & \\
\hline
\end{tabular}

As one may observe the Democratic Party has a slightly smaller share of posts in 2009-2013 than during the period 2005-2009. This reflects the changing in the share of seats in parliament which is very much linked with the changings in the electoral system. The electoral system in 2005 was a mix of single-ballot majoritarian and proportional, where the proportional part aimed at compensating the lost votes that resulted from the majoritarian part (OSCE, 2005, p.4). The system changed in 2009 to regional proportional (OSCE, 2009, p.6). As the result of the elections of 2005, the Democratic Party got 56 mandates in the single-member district (40\% of the total seats), and none in the supplementary seats of the proportional (ODIHR, 2005, p.30). The Democratic Party encouraged its members and sympathizers to vote for its allies, thus enhancing their chances to get seats in parliament. As a result it got 56 seats while its allies benefited from the supplementary seats of the proportional and got 18 seats and thus the right-wing coalition got 74 votes in total. The parliament had 12 political parties and thus even though mainly majoritarian it resulted in plurality (Central Election Commission, 2005).

The elections of 2009 were conducted with a different electoral system: regional proportional. This time it was the Democratic Party which benefited from the votes of its smaller allies and thus it had 68 parliamentary seats out of the 70 that the right-wing coalition got in total (OSCE, 2009, p.33). However this percentage was not sufficient to create a cabinet. Therefore the Democratic Party was forced to create a coalition with a left - wing party, the Socialist Movement for Integration which got 4 parliamentary seats (OSCE, 2009, p.33).

Even though in the elections of 2009, the Democratic Party got more parliamentary seats it has less ministers and vice ministers. Therefore we may conclude that the drivers for ministerial appointments are other than those aimed at achieving policy results as suggested by Blondel $(1995,3-4)$. The negotiations / bargaining are made among political leaders in order to ensure the reach of the party within the polity as well as to strengthen the party and increase its electoral support. An example of this is the Socialist Movement for Integration. The party, a left-wing one, got 5.5\% of the total vote in the parliamentary elections in 2009 (OSCE, 2009, 33). The party made a coalition with the Democratic Party of Albania securing the allocation of three posts of ministers and 6 posts of vice ministers. Only two years later, it has almost doubled its electoral support by achieving a 9.2\% share of the electorate votes (Konrad-Adenauer-Stiftung e.V., 2011 , 4) and during the elections of 2013 it astonishingly increased its number of MPs to 16 by assuring $10.46 \%$ of the total vote (CEC, 2013).

So far we have seen that the appointment of political elites at the level of ministers and vice-ministers is controlled by the party. However this doesn't tell much about the political affiliations of those who fill posts at lower levels of the ministerial hierarchy. One cannot tell whether the staff employment is managed by the party or not. Kopecký and Mair (2011) suggest that for such posts professionalism is a requirement and therefore it is more likely that these positions are no longer recruited through parties as organizations but are nominated instead by individual political actors, i.e. ministers and vice-ministers who draw on personal networks embedded in the professional world. On the other hand, the European Commission's Reports have repeatedly emphasized the final stage in the recruitment process is left exclusively to the discretion of the line manager who in addition to this is also allowed to fill the position with employees under temporary contracts (2010, p.15). This indicates that ministers and vice-ministers draw on their personal network for the recruitment process, but it is difficult to establish whether such network is embedded in the professional world or not. The Progress Reports of the European Commission continually report the lack of qualification of the employees of the public administration as well as continually suggests that the appointment of staff should be based on meritocracy.

However, it is important to give an answer to the question whether the model of democracy, i.e. Westminster and consensual, influence the political appointments. According to Lijphart the proportional representation divides the parliamentary seats among the parties in proportion to the votes they receive and this results in a consensual model of democracy, while the plurality method overrepresent the large parties and this result to a Westminster model of democracy (1999). The analysis of the party system in Albania has shown that this is not always applicable. The share of seats of the small parties was higher in the mix electoral systems than in the proportional one. The following tables show the number of seats that the political parties in Albania got in the 2005 and 2009 elections: 
Table: Official Results for the 2005 Parliamentary Election (OSCE, 2005, 68)

\begin{tabular}{||c|c|c|c|c|c||}
\hline Party & $\begin{array}{c}\text { Number of votes cast for } \\
\text { party and coalition lists }\end{array}$ & $\begin{array}{c}\% \text { of } \\
\text { votes }\end{array}$ & $\begin{array}{c}\text { Single } \\
\text { seats won }\end{array}$ & $\begin{array}{c}\text { Supplementary } \\
\text { mandates allocated }\end{array}$ & $\begin{array}{c}\text { Total number of } \\
\text { mandates }\end{array}$ \\
\hline DP & 104,796 & 7.67 & 56 & 0 & 56 \\
\hline SP & 121,412 & 8.89 & 42 & 0 & 42 \\
\hline AFJW & 457,143 & 33.46 & 0 & 18 & 18 \\
\hline SDP & 174,103 & 12.74 & 0 & 7 & 7 \\
\hline SMl & 114,798 & 8.4 & 1 & 4 & 5 \\
\hline EAP & 89,635 & 6.56 & 0 & 4 & 4 \\
\hline DA & 65,093 & 4.76 & 0 & 3 & 2 \\
\hline SDY & 57,998 & 4.25 & 0 & 2 & 2 \\
\hline HRUP & 56,403 & 4.13 & 0 & 2 & 1 \\
\hline Indep & & & 1 & 0 & 140 \\
\hline & & & 100 & 40 & \\
\hline
\end{tabular}

Table: Parliamentary Elections, 28 June 2009 (OSCE, 2009, 33)

\begin{tabular}{|c|c|c|}
\hline Electoral Subject & Votes & Mandates \\
\hline \multicolumn{3}{|c|}{ Alliance for Change } \\
\hline Democratic Party & 610,463 & 68 \\
\hline Party for Justice and Integration & 14,477 & 1 \\
\hline Republican Party & 31,990 & 1 \\
\hline 13 other parties & 55815 & 0 \\
\hline Sum & 712,745 & 70 \\
\hline \multicolumn{3}{|c|}{ Socialist Alliance for Integration } \\
\hline Socialist Movement for Integration & 73,678 & 4 \\
\hline 5 other parties & 10729 & 0 \\
\hline Sum & 84,407 & 4 \\
\hline \multicolumn{3}{|c|}{ Union for change coalition } \\
\hline Socialist Party & 620586 & 65 \\
\hline Human Rights Union Party & 18078 & 1 \\
\hline 4 other parties & 50084 & 0 \\
\hline Sum & 688748 & 66 \\
\hline Total votes & $1,519,176$ & 140 \\
\hline
\end{tabular}

Table: Parliamentary Elections, 23 June 2013 (CEC, 2013)

\begin{tabular}{|c|c|c|}
\hline Electoral Subject & Votes & Mandates \\
\hline \multicolumn{3}{|c|}{ Alliance for Employment, Welfare and Integration } \\
\hline Democratic Party & 528,373 & 50 \\
\hline Party for Justice and Integration & 44,957 & 4 \\
\hline Republican Party & 52,168 & 3 \\
\hline 22 other parties & 55,179 & 0 \\
\hline Sum & 680,677 & 57 \\
\hline \multicolumn{3}{|c|}{ Alliance for European Integration } \\
\hline Socialist Party & 713,407 & 65 \\
\hline Socialist Movement for Integration & 180,470 & 16 \\
\hline Human Rights Union Party & 14,722 & 1 \\
\hline Christian Democratic Party & 7,993 & 1 \\
\hline Other 33 parties & 77,312 & 0 \\
\hline Sum & 993,904 & 83 \\
\hline Total & & 140 \\
\hline
\end{tabular}


In order to understand the number of parties in the party system, it is used the index of Laakso and Taagepera $\left(\mathrm{N}=1 / \Sigma \mathrm{Si}^{2}\right)$ (in Lijphart, 1999, p.68). The result is that in 2005 there are 3.68 political parties; in 2009 there are 2.2 and in 2013 there are 2.8. This shows that it is not possible to apply any of the models of democracy and hence it is not possible to derive any conclusion from this. On another level, the level of patronage remained the same even though the electoral system changed. Therefore, we may conclude that patronage is exercised to the same extend whatever electoral system is applied and whatever the party system is.

\section{The Relationship between the Structure of the Party, the Appointment of Political Elites and Patronage}

In this section I will explore the structure of the Democratic Party of Albania and what implication does it have to the success of the party. The literature on the structure and model of the political parties in the new democracies contend that the political parties in new democracies displays the same features of the parties in the long-established Western European democracies. Therefore, these parties have weak partisan and strong electoral linkages, reduced relevance of party members, predominance of professionals and party leadership and assimilation into the state (Katz and Mair, 1995 in van Biezen, 2003). However, in contrast to what is expected, the Albanian Democratic Party is a mass party. It accounts around 75,000 members (Kajsiu, 2005, pp.143; Democracy International, 2006, pp.19). According to Duverger, the mass party is based on the principle of membership and members carry out the activities of the party. It is centralized, disciplined, based on the branches and firmly knit (1954, pp.63). The reason for considering it a mass party is because it is organized in a hierarchical fashion with branches and sub-branches distributed all over the country. According to the statute, the Organs of the Democratic Party are: The Assembly and the National Conference, The National Council, The Presidency of the Party and the National Control Commission (Article 15). Furthermore Article 14 stipulates that it is organized on the basis of territory. It is organized in sections, branches and sub-divisions.

The aim of the party is to maximise the membership and penetrate very deep in society. An example of this is the preparation of the party for the local elections of 24 July 1996. The Democratic Party started the preparations since October 1995. The preparations consisted to the reorganization of the all branches, and sub branches of the party. The members were instructed to be in close contact with the people of their community and keep detailed lists on the voters' preferences. Expressions such as 'Return to the base' were articulated on the 5th Anniversary of the party (12 December 1995) to express the importance of the membership. Furthermore the party put much effort to increase the membership all over the country. In December 1995 it had 2,407 sections in all the districts. In the end of 1995, the Democratic Party had become a purpose on itself. Therefore, on the occasion of the 5th anniversary of the party, the Structure and Organization Secretary declared that the 'consolidation of the structure of the party, was the most important organizational activity of the Democratic Party; (Political Notes, 1995, p. 26). The party's strategy to win the elections was its regeneration and penetration in society (Political Notes, 1995, p.24-34). It is also important to mention that the party organizations, branches and sub-branches are formed around the polling stations and electoral districts (Kajsiu, 2005, p.143). In this way the party is able to design its strategy based on electoral districts for having better results.

There are other evidences which prove that the Democratic Party of Albania is a mass party. The declaration of the leaders of the party and the statute of the organization are not sufficiently convincing. They should be back up by other data, to prove the discipline of the membership, and its penetration in society. This is an example already provided in the section for elections. Therefore, I will not go into details but will just emphasize the discipline of the party members obey to the decisions of the central party for the parliamentary elections of 2005. When the Democratic Party of Albania called for its electorate to vote for the coalition parties in the proportional, the call resulted successful. The formula worked very well and the Democratic Party won the election. However, there was a lot of extensive work of the party members to put the plane in practice. The members distributed the materials, knocked on the doors of party's supporters and explained to them the scheme. The party had detailed lists with the names of its supporters and thus it managed to give the message to all of them. It is important to mention that in 2005, the Democratic Party was in opposition and as such it didn't have the support of the government machinery. Nonetheless, the members made possible the successful implementation of the scheme. Consequently, the membership, in addition to other factors such as ideological crafting, contributed to the success of the party.

To this point, it is important to explore the reasons for the emergence of the mass party in Albania. There is a plethora of scholars who argue that the new democracies in the post communist countries are not experiencing the same path of party development that took place in the West. They claim that the mass party is passé and other models of party organization, such as the catch-all, professional-electoral or cartel could better suit to the political parties in Central and Eastern Europe (Lewis, 1996, p.10). Van Biezen, also argues that the parties in the new democracies experience weak 
partisan and strong electoral linkages, reduced relevance of party members and predominance of professional and party leaderships. The parties in new democracies have adopted the organizational style of the parties in the old democracies. According to her it is not the sheer newness of democracy what matters but the institutional context and the period in which parties develop (2003, p.218-219).

However, I do not agree with such hypothesis. The emergence of mass parties, according to Duverger, is linked with the universal suffrage $(1954$, p.65). The masses who were not allowed to participate in the political sphere, all of a sudden were allowed to do so. With the collapse of communism and the emergence of democracy experience, the people experienced the same phenomenon: universal suffrage. It is true that during the communist system, the citizens were entitled to vote, however that was not a free vote. It was commanded from the Party, therefore the concept of voting was devoid of its meaning. The concept of vote is linked with that of selection and selection with that of alternatives. But during the communist period, the people didn't have any alternative and therefore no selection took place. With the collapse of communism, process of voting took its meaning. The vote of the people had an effect on the political sphere. They could decide. The only difference with the model of Duverger is that the emergence of the mass party reflected the differences in the social and political substructure. The mass party represented the working class and belonged on the left of the political spectrum (1954, p.67). In the Albanian cases, the masses were a heterogeneous combination of people. Even though it is difficult to speak of classes in a communist regime, it is still possible to distinguish the working class, the peasantry and the intellectuals. The working class, which historically in the Western countries has been contingent of the left-wing parties, in the Albanian case, was a contingent of the right-wing parties.

The Democratic Party of Albania is the only party in the centre - right which could be considered as a mass party. The other parties too tend to have a structure based on membership, but they do not share the same high levels of membership and electorate of the Democratic Party, therefore they cannot be considered as mass parties. An attempt to explain the success of the Democratic Party will be to use genetic and institutionalization model of Panebianco. According to Panebianco, a party's construction and development is due to territorial penetration or territorial diffusion (1988, p.49-51). In the first case, the party in centre penetrates the territory by organizing the local branches. While in the second case, the party which emerges in periphery attempts to get integrated in the national organization. According to Panebianco, 'development through penetration produces strong institutions, while development through diffusion tends to produce weak institutions' (1988, p.63). The Democratic Party of Albania belongs to the first group. It was created in the centre and then managed to penetrate the territory. The process was made easier because it corresponded with the mobilization of the masses to overthrow the communist regime, and therefore the mobilization of them in the ranks of the Democratic Party was proved to be successful. However, it remained to be explored, why the other centre-right parties couldn't manage to reach territorial penetration, even though the strategy they followed was similar with that of the Democratic Party. However, the model could explain only the success of the Democratic Party and not the failure of the other centre-right parties. One explanation could be that being the first political party which emerged as a product of the students' protests of December 1991, to overthrow the communist regime, the Democratic Party had the opportunity to gather almost the whole share of the anti-communist electorate and found a mass party with extensive penetration in society.

There is a final consideration with regard to the structure of the party and the relations it has with its membership. The 2001 elections, proved to be somehow difficult for the Democratic Party of Albania. For the first time, it experienced a strong competition from a centre-right party. The emergency of the New Democratic Party of Albania, as a splinter group from the Democratic Party, proved to be successful for the last one. It managed to get $5.3 \%$ of the total votes, and around $12 \%$ of the total right vote. Nonetheless the party didn't manage to repeat the same success later. Therefore it is important to explore the reasons of this electorate loyalty, towards the Democratic Party.

A hypothesis on the electoral loyalty is that of patronage and clientelistic relations that the Party has established with its supporters (Kajsiu, 2008, p. 53-54). In a "Material for Press", prepared for the Democratic Party's Presidency members, on 27 March 1995, some of the comments and recommendations with regard to the press are as followed. The press was divided in 'pro' and 'con' the government and then it was advised that the government should support the press that is 'pro' its programme. The support consisted in providing them with low interest credits or construction land so that the staff that was experiencing difficulties in accommodation could solve this problem. Furthermore, the 'pro' press had to be provided with offices (1995, p.3-4). The Material on Press is an internal document which indicates how the party which at the time was in power, had the opportunity to reward its supporters. Furthermore, in the elections of 1996, the Democratic Party, at the time in power, used the central and local government staff for its electoral campaign and for the pre-elections preparations phase (Political Notes, 1995, p.28, 34). Therefore the boundaries between state employees and party members were blurred. The situation was repeated when the Democratic Party came to power in 
2005. The state administration staff experienced a high staff turnover, due to people being terminated their contracts arbitrary based on political convictions. There is a series of reports issued for the international organizations that operates in Albania who have observed as concerning the political appointments of staff administration (Freedom House, 2006, p.6-7; Commission of the European Communities, 2007, p.8; 2009, p.9; EU Enlargement, 2006, line 15). A poll organized by the Ministry of Integration in 2007, indicated that 27.8\% of the Public Administration staff had been employed in the current position in the last two years (Kajsiu, 2008, p.52). Therefore, with coming to power, the Democratic Party employed a system of reward for its supporters, by offering them jobs in the public administration. Kajsiu claims that the politics of patronage is the only way the political parties could mobilize their supporters and ensure their loyalty (2008, p.52).

I have argued here that the structure of the organization is important in the success or failure of a party. Therefore, being a mass party with an extensive membership that has penetrated deep in society, the Democratic Party has been able to implement its electoral strategies as well as ensure a loyal electorate. However, the relation of the party with its electorate consists in a system of distribution of incentives (jobs) in return for the loyalty. Therefore, the Democratic Party has ensured a party of its supporters through patronage.

\section{Conclusion}

The research was focused on the following points:

1. The extent to which political parties can control the allocation of jobs as well as find out which are the institutions over whom the political parties can exercise power. Subject of analysis have posts of ministers and vice-ministers, posts in high level in ministries and posts in the office of general attorney.

2. The extent to which historical legacies influence patronage patterns.

3. 3-The extent to which party patronage is exercised in a 'majoritarian' as opposed to a more 'consensual' manner across the spectrum of political parties. While Albania has for long been a 'Westminster' model of democracy (Lijphart 1999) - with the change of the electoral system in 2009 from mainly majoritarian towards proportional it has shifted a bit towards a more consensual model of democracy.

4. The relationship that exist between the structure of the party, the appointment of political elites and patronage.

The conclusion is that the party in public office and its allies in the coalition cabinet control the post of ministers and vice-ministers. While this last ones control the posts of their subordinates, it is hard to understand whether they select the employees from the party pool or from their personal networks. The other finding is that the structure of the party creates strong links between patronage and appointment, these last ones done with the scope of having control over government resources and distribution of resources. On the other hand the research didn't prove any link between historical legacies and patronage and party system and patronage.

\section{Acronyms}

$\begin{array}{ll}\text { DA } & \text { Democratic Alliance } \\ \text { DKP } & \text { Democristian Party } \\ \text { DP } & \text { Democratic Party } \\ \text { HRUP } & \text { Human Rights Unity Party } \\ \text { NF } & \text { National Front } \\ \text { PJIU } & \text { Party for the Justice, Integration and Unity } \\ \text { PL } & \text { Party of Legality } \\ \text { RP } & \text { Republican Party } \\ \text { SMI } & \text { Socialist Movement for Integration }\end{array}$

\section{References}

Blondel, J. (1995) ‘Party Government: Myth or Reality’, IHS Reihe Politikwissenschaft No. 20.

Albanian Helsinki Committee (2011) Report - The situation of discrimination in the process of work dismissal in Albania', December 2011.

Blondel, J. (1995) The Links between Appointments, Policy-making and Patronage in Government - supporting Parties Relationships, Working Paper n.101, European University Institute. Available at: http://www.recercat.net/bitstream/handle/2072/1366 /ICPS101.pdf?sequence=1. 
Bogdani, M., Loughlin, J. (2007) Albania and the European Union: The Tumultuous Journey Towards Integration and Accession, I.B.Tauris.

Bozòki, A. \& Ishiyama, J.T. (2002) The Communist Successor Parties of Central and Europe, New York \& London: M.E.Sharpe.

Cohen, L.J. (2010) Administrative Development in 'Low-Intensity' Democracies: Governance, Rule-of-Law and Corruption in the Western Balkans, Simons Papers in Security and Development, No.5.

Collier, R. B. and David Coller (1991) Shaping the Political Arena. Critical Junctures, the Labor Movement, and Regime Dynamics in Latin America, Princeton: Princeton University Press

Commission of the European Communities (2005) Albania - 2005 Progress Report. Available at: http://ec.europa.eu/enlargement larchives/pdf/key_documents/2005/package/sec_1421_final_progress_report_al_en.pdf.

Commission of the European Communities (2006) Commission Staff Working Document - Albania 2006 Progress Report. Available at: http://ec.europa.eu/enlargement/pdf/key_documents/2006/nov/al_sec_1383_en.pdf.

Commission of the European Communities (2007) Commission Staff Working Document - Albania 2007 Progress Report. Available at: http://ec.europa.eu/enlargement/pdf/key_documents/2007/nov/albania_progress_reports_en.pdf.

Commission of the European Communities (2008) Commission Staff Working Document: Albania 2008 Progress Report accompanying the Communication From the Commission to the European Parliament and the Council - Enlargement Strategy and Main Challenges 2008-2009. Available at: http://ec.europa.eu/enlargement/pdf/press_corner/key-documents /reports_nov_2008/albania_progress_report_en.pdf.

Commission of the European Communities (2009) Commission Staff Working Document: Albania 2009 Progress Report. Available at: http://eeas.europa.eu/delegations/albania/documents/eu_albania/2009_progress report en.pdf

Commission of the European Communities (2010) Commission Staff Working Document: Albānia 2010 Progress Report. Available at: http://ec.europa.eu/enlargement/pdf/key_documents/2010/package/al_rapport_2010_en.pdf.

Commission of the European Communities (2011) Commission Staff Working Document: Albania 2011 Progress Report. Available at: http://ec.europa.eu/enlargement/pdf/key_documents/2011/package/al_rapport_2011_en.pdf.

Commission of the European Communities (2012) Commission Staff Working Document: Albania 2012 Progress Report. Available at: http://ec.europa.eu/enlargement/pdf/key_documents/2012/package/al_rapport_2012_en.pdf.

Elbasani, E. (2009) EU Administrative Conditionality and Domestic Dowñloading - The Limits of Europeanization in Challenging Contexts, Working Paper KFG, The Transformative Power of Europe, No.2, Freie Universitat Berlin. Available at SSRN: http://ssrn.com/abstract=1956888 or http://dx.doi.org/10.2139/ssrn.1956888.

Freedom House (2012) Country Report: Albania. Available at: http://www.freedomhouse.org/country/albania.

Grzymala-Busse, A. M. (2002) Redeeming the Communist Past. The Regeneration of Communist Parties in East Central Europe, Cambridge: Cambridge University Press.

Grzymala-Busse, A. M. (2006) 'Authoritarian Determinants of Democratic Party Competition: The Communist Successor Parties in East Central Europe', Party Politics 12(3), 415-437, DOI: 10.1177/1354068806063089].

Hanley, S., Szczerbiak, A., Haughton, T. and Fowler, B. (2007) 'Explaining the Success of Centre-Right Parties in Post-Communist East Central Europe: A Comparative Analysis', Sussex European Institute Working Paper No 94, [available at http://www.sussex.ac.uk/sei/1-4-10-1.html].

Hanley, S., Szczerbiak, A., Haughton, T. and Fowler, B. (2008) 'Sticking Together: Explaining Comparative Centre-Right Party Success in Post-Communist Central and Eastern Europe', Party Politics, 14: 407-434

Hopkin, J. (2006) Conceptualizing Political Clientelism:Political Exchange and Democratic Theory, Paper prepared for APSA annual meeting, Philadelphia, 31 August - 3 September 2006. Available at http://personal.Ise.ac.uk/hopkin/apsahopkin2006.pdf.

Kajsiu, B. (2004) 'Albanian Political Parties', pp.9-38 in Georgi Karasimenov (eds.) Political Parties and the Consolidation of Democracy in South Eastern Europe, Gorex Press Publishing House: Sofia.

Kajsiu, B. (2005) 'Organizational Structure and Internal Party Democracy in Albania', pp.142-165 in Georgi Krasimeonov (eds.) Organizational Structures and Internal Party Democracy in South Eastern Europe, Gorex Press Publishing House: Sofia

Kitschelt, Herbert, Mansfeldova, Zdenka, Markowski, Radoslaw, Tóka, Gábor (1999) Post-Communist Party Systems - Competition, Representation and Inter-Party Cooperation, Cambridge University Press.

Konrad-Adenauer-Stiftung e.V. (2007) Rezultatet e zgjedhjeve lokale të 8 majit 2011 në Shqipëri (The results of the local elections held on 08 May 2011 in Albania), 07 june 2011. Available at: http://www.kas.de/wf/doc/kas_23034-1522-33-30.pdf?110628122234

Kopecký, P. \& Mair, P. (2011) Party Patronage in Contemporary Europe: Principles and Practices, EUI Working Papers, RSCAS/41. Available at: http://www.eui.eu/Projects/EUDO/Documents/2011/eudoworkingpaperkopeckymair.pdf

Mahoney, J. and Richard, S. (1999) 'Rethinking Agency and Structure in the Study of Regime Change', Studies in Comparative International Development, Summer 1999: 3-32.

Mahoney, J. (2001) 'Path-Dependent Explanations of Regime Change: Central America in Comparative Perspective', Studies in Comparative International Development, Spring 2001, Vol.36, No.1, pp.114-141.

Mahoney, J. (2000) "Path Dependence in Historical Sociology," Theory and Society, 29: 507-548.

OSCE/Office for Democratic Institutions and Human Rights (ODIHR). Needs Assessment Mission Report, 12-16 April, Warsaw, April 2005, Available at: http://www.osce.org/odihr-elections/14376.html.

OSCE/Office for Democratic Institutions and Human Rights (ODIHR). Republic of Albania: Parliamentary Elections, 3 July 2005. Warscaw, November 2005. Available at: http://www.osce.org/odihr-elections/14376.html

OSCE/Office for Democratic Insittuions and Human Rights (ODIHR) (2009) Republic of Albania. Parliamentary Elections - 28 June 
2009. OSDCE/ODIHR Election Observation Mission Final Report, 22 October 2009. Available at: http://www.osce.org /documents/html/pdftohtml/39545_en.pdf.html

Panebianco, Angelo (1988) Political Parties - Organization and Power, Cambridge: Cambridge University Press.

Parliamentary Commission (2006) Report for the 'Investigation of the Dismissals in the Public Administration', Albanian Parliament. Pierson, P. (2000) 'Increasing Returns, Path Dependence, and the Study of Politics', American Political Science Review 94: $251-267$. Pierson, P. (2004) Politics in Time, Princeton: Princeton University Press.

Van Biezen, I. (2003) Political Parties in New Democracies - Party organization in Southern and East-Central Europe. Hampshire: Palgrave MacMillan 